\title{
THE GRASSLAND RESEARCH INSTITUTE
}

$I^{\mathrm{N}}$ $N$ the past, grassland has received much less than its due share of attontion from the scientist, but some of the extensive work on this subject now being done in Great Britain is summarized in the recently published annual report for 1957-58 of the Grassland Research Institute (Experiments in Progress, No. 11. Pp. 108. Hurley, near Maidenhead : Grassland Research Institute, 1959. 7s. 6d.). Many aspects of the composition, treatment and use of grassland swards are investigated by the nine departments. The Department of Herbage Agronomy is concerned with management, yield and quality of herbage at all seasons of the year, and the emphasis has shifted from comparison of species and varieties to establishment and management of the sward. Continuation of the study of the relationship between white clover and top-dressings of nitrogenous fertilizer has shown that the effect of white clover on gross yield of herbage was equivalent to approximately 9 cwt. per acre of a nitrogenous fertilizer annually on a no-clover sward. The results of experiments with gibberellic acid showed that response to nitrogenous fertilizer at 4: ewt. per acre was greater than response to $2 \mathrm{oz}$. per acre gibberellic acid. Nitrogen plus gibberellic acid produced an additive effect at first, but in the presence of nitrogen there was a significant dopression in yield as a result of gibberellic acid treatment ; depression was greatest where the initial response to gibberellic acid was marked.

In the Section of Animal Agronomy, grassland production is measured in terms of the animal. Better live-weight performance per animal was obtained when cocksfoot was grown with lucerne than when lucerne was grown alone. A comparison of two methods of sowing and managing lucerne and cocksfoot indicates that it is possible to extend the grazing season by about four weoks in the autumn by use of nitrogenous fertilizers. The live-weight gain per acre of ewe lambs carried throughout the year at a stocking rate of 6.1 per acre was, on average, $65 \mathrm{lb}$. higher on swards containing white clover, although the grass swards received nitrogen to compensate. The comparative influence of leys, variously managed, on the yield of subsequent cereal and kale crops has been investigated by the Department of Ley Agronomy. It is demonstrated that management of ley swards has an appreciable effect on yield of the following crops. This is accounted for largely by the nitrogen status of the soil. The study of the intake and digestibility of herbage is one of the main concerns of the Department of Biochemistry and Animal Nutrition. This involves both feeding experiments and biochemical studies of herbage plants. The former have shown that certain of the major grasses are more digestible than others and the latter that the older methods of fractionation are too arbitrary; modern techniques are likely to give a more reliable assessment of digest. ibility.

The work of the Department of Plant Physiology is linked with that of Herbage Agronomy in laboratory and field. The detailed growth studies are likely to provide valuable guidance on grazing practice. Experiments in microbiology are connected to soil and herbage studies in other departments, with emphasis on the examination of the processes of decomposition which take place when the ley is ploughed. A small exporiment on sterilization of grass by radiation suggests that it may be possible to preserve grass for several months without undue changes in palatability. Extra-mural experiments provide supplementary evidence over a wide variety of environmental conditions. Such experiments are usually done in collaboration with the National Agricultural Advisory Service. The Department of Biometrics provides statistical advice and a computing service for other departments and has commenced its own field-experiments to answer specific questions.

\section{SCIENTIFIC RESEARCH IN ALBERTA}

$\mathrm{T}$ HE thirty-ninth annual report of the Research Council of Alberta, covering the year 1958, stresses the work on ground water geology and the studies on the Precambrian Shield area of northeast Alberta (Report No. 78. Pp. 66. Edmonton : Research Council of Alberta, 1959). Work was commenced on the delineation of areas with large coal reserves which could be developed by industry as a source of power, and reconnaissance surveys were made of alkali lakes in Alberta and of tho mountains west of Nordegg. A laboratory study of till from the Cooking Lake moraine showed that electrical potentials up to $0.5 \mathrm{~V}$. can be generated in soil between individual horizons by natural processes. Soil surveys continued and a study is being made to determine the characteristics of the dominant parent materials of Alberta soils, the composition of the glacial till and the local variations. Further work at Youngstown showed that the productivity of the solonetz soils was limited by the physical condition of the soil, times and timeliness of irrigation being both critical under such soil conditions. The hail reporting net- work was furthor extended and valuable results were obtained in spite of an unusually low incidence of hail in the area. The highway research programme was largely concerned with the instrumentation and study of a five-mile portion of the trans-Canada highway west of Calgary, on which test sections of three different types of concrete pavement were laid.

Fundamental studies on coal in the organic chemistry laboratory included an examination of reactions of humic acids, a preliminary survey of the properties of kerogens and other organic sub. stances associated with inorganic sediments, and substantial progress in the separation of the products obtained by oxidizing pyrolysed truxene with nitric acid. The main effort of the physical chemistry laboratory was in studies of the mechanism of thermal decomposition of coal and the control of the decom. position by gaseous and gas-entrained additives; but the effects of ultrasonic irradiation on small molecules were also examined and the viscosity characteristics of solvent extracts from coal and the shape and size 
of the extracted molecules. In palæobotany, substantial progress was made in formulating means for identifying fossil spores and pollen grains, and the development of a 'key' for identifying living and fossil conifer woods is now virtually complete. Further studies are reported on fluidized carbonization, and the first stage of a coal grindability investigation was completed. In the petroleum division studies continued of the catalytic desulphurization of sulphur compounds at high temperatures to remove sulphur as hydrogen sulphide and on the oxidation of sulphur compounds to remove it as sulphate. The study of two-phase flow of oil and water in pipe-lines was continued, in which a general mathematical analysis was developed for two immiscible fluids flowing between wide parallel plates and flowing concentrically in a circular pipe. Considerable progress was made in the study of the effects of hydrogen isotopes on the rates of chemical reactions, while the study of the retention volumes of hydrocarbon gases on chromatographic columns of a series of activated charcoals has been extended to an examination of the relative widths of the chromatographic bands. The autothermic surface combustion reactor for pyrolysing hydrocarbons was further developed. A list of publications of the Council is appended.

\section{BIOLOGY OF AMEBA}

$\mathrm{T}$ HE late Robert Chambers was a much-loved personality on both sides of the Atlantic. A publication by the New York Academy of Sciences has been greatly influenced by him, many papers being presented by his former students and 'second generation' of students*. The papers deal exclusively with the 'fission cycle' of the life-history of Amoeba. I first made acquaintance with Chambers when studying Daphnia pulex, each having worked out its spermatogenesis. Later, I sent to him supplies of $A$. proteus at various localities.

An article by Mazia in "Science in Progress"' prepared readers for some of the many good things in this volume. After a short biography of Chambers and an introduction by Hirshfield, the subject-matter is grouped into four parts. In part 1 ("Structural and Taxonomic Considerations"), Torch describes the cytology of Pelonyxa. The most interesting conclusion is that crystals are a metabolic waste product, probably an accessory mechanism for the excretion of nitrogen. Particulates of Amøebr are studied by Kassel using a drop-retraction technique; proteins on reaching an experimentally introduced oil-water interface unfold and produce a surface denaturation curve resembling that of a medium containing a protein of low molecular weight. Useful practical hints and photographs of apparatus, as well as electron microscope studies, are given in "Microscopic Studies" by Borysko and Roslansky. Beautiful electron microscopic work by Pappas reveals the astounding presence of fine fibrous extensions on the outer surface of the plasmalemma of three species of amoba, and other unsuspocted structures. Kudo gives a welcome résumé of the work of the early observers and their nomenclature and makes a strong plea for the retention of the name Amoeba for the genus.

In part 2 ("Physical Studies and Cell Division") Landau deals with sol-gel transformations in Amœbæ, and considers that the findings of myosin-like proteins in amoeboid forms lend credence to the idea of a contractile substratum. "Synchronization of CellDivision" by James gives much fascinating detail of the observations made during the establishment of the main thesis. Three authors describe pinocytosis, which was discovered by Lewis, and observed by Mast and Doyle in amœbæ, but only recognized as important in the past few years. Holter, in the next paper, gives some beautiful pictures of the phenomenon, and stresses its im-

* Annals of the New York Academy of Sciences. Vol. 78, Art. 2 : The Biology of the Amneba. By Henry I. Hirshfield and 22 other authors. Pp. 401-704. (New York: New York Academy of Sciences,
1959.) 4.50 dollars. portance in the physiology of amoboid cells, though he thinks that the original definition may require modification towards less emphasis on the fluid uptake and more on the dissolved substance.

A very long paper of sixty-three pages by Guthwin and Kopac is a vade-mecum for the microscopic enzyme chemistry of carboxylic esterases in Amœbæ. "Cytochemical Differentiation in Normal and Starving Amobæ", by Heller, is the second article of part 3. An interesting analysis of the cytoplasmic inclusions deals with refractive bodies. As I have repeatedly pointed out, these refractive bodies are nutritive, and for that reason Dr. Carmela Hayes renamed them 'nutritive spheres'. They play a great part in the formation of the spores in the Proteus group of Amcebæ. Their diameter is indicative of the age of the Amoba-an individual with large nutritive spheres is old and ready to sporulate. Cohen, in "Physiological and Morphological Observations", gives the first hint as to the great weakness of the work under review when he says, "A. proteus in our experience consists of at least two strains ... investigators should give the history of the stock they use". I maintain that two distinct species masquerade under the specific name proteus. I have had an opportunity of studying a rich culture from the laboratory of Brachet: it was $A$. lescherae and not $A$. proteus. It also contained very young stages of development, proving that even under rigid subculturing a few individuals escape and sporulate. Want of space prohibits more than mention of "Tracer" Studies in Amoebæ" by Plaut, "Effect of Selected Chemical Agents on Amœebæ" by Zimmerman.

In part 4 Hirshfield discusses "Nuclear Control of Cytoplasmic Activities" and Prescott pictures the wonderful Cartesian diver for weighing Ámœbæ in his article on microtechnique in amœbre studies. "Mierurgical Studies on Irradiated Pelomyra", by Daniels, is followed by an account of the celebrated work of Danielli on strains of Amnebr that have been continuously cultivated for years in King's College, London. In conclusion, one would urge the examination of older Amoba for the presence of deoxyribonucleic acid. Brachet's beautiful work on the "Cytoplasmic Dependence in Amoeba" evidently omits this. The volume ends on a lighter vein when Kopac visualizes Amœeba research in 2158. Used in conjunction with Jepps's "The Protozoa, Sarcodina", this volume is a useful reference book for all students of Amoba. Monica TAYLOR

1 "Science in Progress", edit. by Taylor, Hugh, 10th Series (New Haven, Yale).

"Jepps, M. W. "The Protozoa Sarcodina" (Oliver and Boyd, Cdinburgh, 1956). 